Andjelka Pejović

Universidad de Belgrado

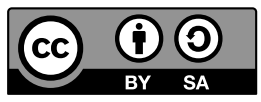

\author{
Barbara Pihler Ciglič
}

Universidad de Ljubljana

\title{
Acerca del continuum paremiológico ${ }^{1}$
}

Palabras clave: paremia, refrán, proverbio, antirrefrán, aforismo, continuum paremiológico

«La polisemia del lenguaje constituye el combustible del pensamiento.»

(Eugenio Trías)

\section{Introducción}

Hace dos décadas Combet (1996: 11-12) señaló que la filosofía expresada en los refranes y proverbios de las culturas y civilizaciones antiguas, incluso desaparecidas, casi no se diferencia de la filosofía en los proverbios actuales: en ella están presentes las mismas cuestiones que tienen que ver con la vida diaria, las relaciones familiares, el amor, el poder, la muerte, etc. Por tanto, los refranes y proverbios ayudan a entender el mundo, la naturaleza, pero también la índole humana, el ser humano (Amando de Miguel, apud Junceda, 2003). Y, como la realidad misma es muy variada y contiene fenómenos contrarios, esas oposiciones también se reflejan en la lengua y de ahí en la fraseología y la paremiología. Torrente Ballester (Junceda, 2003: X) recuerda que «los refranes pierden eficacia cada vez que las cosas de este mundo cambian y adquieren para quienes las viven un sentido distinto, otra orientación». Se puede decir, por

$1 \quad$ Este trabajo se enmarca en dos proyectos de investigación: (1) el proyecto de investigación 178014, financiado por el Ministerio de Educación, Ciencia y Desarrollo Tecnológico de la República de Serbia; y (2) el proyecto de investigación P6-0218, financiado por la Agencia Pública de Investigación de la República de Eslovenia. 
tanto, que los refranes tienen «fecha de caducidad». En relación a las paremias en general y a los refranes y proverbios en particular, Conde Tarrío también subraya el carácter documental y pasajero de estas construcciones: «la paremia nace como vehículo que usa el pueblo para transmitir sus conocimientos a sus descendientes» $\mathrm{y}$ «es [...] un documento que nos permitirá conocer la vida y las costumbres de otras épocas, es decir, con ella nos acercaremos al pensamiento de nuestros ancestros» (Conde Tarrío, 2007: 5). Entonces, si en las paremias se refleja la manera de vivir, es lógico que la línea trayectoria de su desarrollo no sea estrictamente lineal; vemos en ella más bien un continuum. Pejović (2015) en su investigación sobre el continuum fraseológico lo ilustra con ejemplos en español y en serbio, mostrando en qué manera las colocaciones, por un lado, y los refranes, por el otro, se convierten en locuciones, esto es, unidades fraseológicas stricto sensu.

En este trabajo nos proponemos como objetivo presentar el continuum paremiológico con ayuda de ejemplos en español, serbio y esloveno. El interés por el tema surge a partir la presencia significativa de distintos tipos de construcciones paremiológicas en la vida contemporánea, cuya difusión se ve apoyada por los medios de comunicación, las nuevas tecnologías y las redes sociales. Basamos nuestro estudio en trabajos paremiológicos relevantes, por un lado, $y$, por el otro, en colecciones de paremias, refraneros, antologías de aforismos, blogs, etc.

\section{Paremias: tipología y características}

Sevilla Muñoz y Crida Álvarez (2013) definen la paremia como «una unidad fraseológica constituida por un enunciado breve y sentencioso, que corresponde a una oración simple o compuesta, que se ha fijado en el habla y que forma parte del acervo socio-cultural de una comunidad hablante» (Sevilla \& Crida Álvarez, 2013: 105). Los mismos autores clasifican las paremias según el origen (distinguiendo entre paremias de origen conocido y paremias anónimas) y según el uso (culto o popular). La paremia de origen conocido y de uso preferentemente culto es «el enunciado sentencioso extraído de un texto o de un hecho, el cual participa de las características generales de las paremias y cuyo uso actual puede ser culto o popular. Las paremias de origen conocido coinciden, en parte, con lo que Corpas llama citas [...]» (Sevilla Muñoz \& Crida Álvarez, 2013: 108). Al grupo de las paremias conocidas y de uso culto pertenecen el proverbio y el aforismo, que podemos encontrar en la Biblia, literatura, historia, mitología, propaganda política, etc. Si nos atenemos 
a sus definiciones, el proverbio es «es un enunciado sentencioso de origen conocido, cuyas características son la procedencia culta, la antigüedad, el tono grave, la gradación idiomática, la potencial variación y el uso preferentemente culto» (Sevilla Muñoz \& Crida Álvarez, 2013: 109) mientras que por otro lado el aforismo sería «un enunciado sentencioso de origen conocido, cuyas características son la procedencia culta, el potencial conocimiento del autor, el tono grave, el alto grado de fijación interna, la gradación idiomática, la escasa variación y el uso preferentemente culto» (Sevilla Muñoz \& Crida Álvarez, 2013: 109). Entre estos últimos, los autores destacan aforismos éticos, políticos y aquellos de origen científico o profesional.

En lo que se refiere a la paremia de origen anónimo, Sevilla Muñoz y Crida Álvarez (2013: 11) entienden por este término «el enunciado sentencioso, por lo general de uso popular, el cual participa de las características generales de las paremias, pero cuyo origen nos es desconocido», e incluyen en este grupo el refrán, la frase proverbial, la locución proverbial y el dialogismo. La paremia anónima y de uso popular, la paremia por excelencia, es el refrán ${ }^{2}$. No obstante, algunas paremias de origen conocido pueden ser utilizadas sin hacer referencia al autor, es decir, como anónimas, cuando los hablantes o bien no saben quién es su autor, o bien no les interesa. Por otro lado, también puede darse el caso de que un refrán anónimo encuentre lugar en obras literarias, como en el caso de El Quijote, que ha inspirado tantos estudios e investigaciones sobre estas construcciones paremiológicas. ${ }^{3}$

Sin embargo, a pesar de la distinción terminológica planteada anteriormente, la diferencia entre proverbios y refranes se hace imprecisa, y no extraña que se hable de refranes y proverbios indistintamente. $Y$, si a esto añadimos que en los refranes se observan dos grandes grupos, unos de alcance general (que tratan temas universales, como valores éticos, asuntos económicos, asuntos de salud) y otros, de alcance reducido (como aquellos referentes a la geografía de un país, al tiempo climático, labores, creencias, etc.) (Sevilla Muñoz, apud Sevilla Muñoz \& Crida Álvarez 2013), es evidente que también la frontera entre refranes y aforismos se hace menos clara, puesto que los

2 De hecho, los «Humanistas y los Erasmistas no dudaron en considerar los refranes evangelios breves, cuyas enseñanzas debían ser tan respetables como las de los Evangelios canónicos de la Iglesia Católica» (Combet, 1996: 12).

3 Tarnovska (2006: 369-370) señala entre otros a José Coll, José María Sbarbi, Marcelino Menéndez Pelayo, Amado Alonso, Eleanor O’Kane, Fernando Lázaro Carreter, Elias Olmos, María Cecilia Colombí, Mauricio Molh, Pilar Vega Rodríguez, pero también a Francisco Calero y Amando De Miguel(año). Por otra parte, también destacamos los estudios contrastivos de los refranes de El Quijote en español y esloveno de Pihler Ciglič (2006, 2007). 
aforismos, como ya se ha mencionado, también tratan temas éticos, políticos y de origen profesional.

Aunque forman un grupo muy heterogéneo y tienen procedencia distinta, las paremias comparten algunas características. En cuanto al aspecto formal, presentan «una cierta artificiosidad» (Corpas Pastor, 1996: 151), puesto que en ellas a menudo se pueden encontrar elementos arcaizados, como testimonios de épocas antiguas, de usos lingüísticos antiguos: A donde fueres, baz como vieres (refrán); serb. Udario tuk na luk ('se enfrentaron tuk (golpe) y cebolla/ajo'); esl. Brez muje se še čevelj ne obuje: 'sin muja (el esfuerzo) no puedes ni ponerte los zapatos'). Respecto al contenido semántico, las paremias están motivadas y basadas en experiencias, hechos históricos, tradición, costumbres, creencias, mitos, y vienen disfrazadas de consejos, advertencias, avisos o meros comentarios: No se ganó Zamora en una bora; Agua por San Juan, quita vino y no da pan; A casa de tu bermano no irás cada serano; serb. Kasno Marko na Kosovo stiže ('Demasiado tarde llega Marko a Kosovo'), Posle svetog Ilije, sunce sve milije ('Después de San Elías, el sol se quiere / se aprecia cada vez más'); esl. Sveti Vid je čěsenj sit 'San Vito se harta de cerezas'; Če se Pankracij na soncu peče, obilo mošta v sod priteče: 'Si San Pancracio está al sol, habrá mucho mosto en el barril'). A veces la interpretación del significado de una paremia puede depender del contexto, debido a la naturaleza metafórica de estas estructuras (Corpas Pastor, 1996). Por ejemplo, la paremia A rey muerto, rey puesto, puede emplearse en distintas situaciones: cuando un novio es "sustituido" por otro, o un jefe sustituido por otro jefe, etc. Algunas paremias presentan diferencias de orden diatópico, diastrático y diafásico (Corpas Pastor, 1996). Las citas, pero también los aforismos, pertenecen a un nivel cultural alto, mientras que los refranes, que reflejan un saber popular, corresponden más bien a un nivel cultural bajo o neutro. Como ejemplos de restricción diatópica Corpas Pastor (1996) hace mención de las siguientes paremias mexicanas: Al nopal se le va a ver solo cuando tiene tunas, Es bueno raspar, pero no arrancar los magueyes, etc.

\section{El enredo paremiológico}

En el ámbito paremiológico se utilizan varios términos, como sentencia, máxima, dialogismo, apotegma, adagio, refrán, proverbio, aforismo etc., y entre ellos es muy difícil si no imposible marcar límites claros. La sentencia, para Platas Tasende (2004: s.v. sentencia), «es una reflexión breve que pretende ser válida como norma de conocimiento del mundo. Engloba los adagios, aforismos, 
máximas, refranes y proverbios, algunos de ellos sinónimos o casi sinónimos entre sí». Adagio, tanto para Platas Tasende (2004) como para Estébanez Calderón (2008), es una sentencia con la que se expresa una reflexión de valor moral o una norma de conducta, por lo que es doctrinal. Ambos autores ilustran este término con el siguiente ejemplo (entre otros): Lo bueno, si breve, dos veces bueno; serb. Dvostruko daje ko brzo daje ('Da el doble quien da pronto'); esl. Kdor bitro da, dvakrat da ('Quien da pronto, da el doble'). Platas Tasende (2004: s.v. máxima) define la máxima como «sentencia breve de valor moral o práctico», y de nuevo remite a adagio, aforismo, proverbio y refrán. También Estébanez Calderón (2008: s.v. máxima) ve en la máxima «la expresión de un pensamiento moral en el que se sintetiza una norma de conducta. La máxima presenta carácter de validez universal [...] Es, como el adagio, el aforismo, el proverbio o el refrán, una variedad concreta de la sentencia, que sería su término genérico». Recordamos que Sevilla Muñoz y Crida Álvarez (2013) definen ambos tipos de paremias (de origen conocido y origen desconocido, de uso culto y de uso popular) como «enunciados sentenciosos», con lo cual también ven en la sentencia el hiperónimo que engloba distintos tipos de paremias, de las que en la bibliografía paremiológica, pero también en los escritos no especializados, predominan refrán o proverbio y aforismo.

\subsection{El refrán}

El refrán es considerado paremia par excellence y su uso es probablemente tan antiguo como la necesidad del hombre de socializarse (Conde Tarrío, 2007: 5). Mieder (2000: 17) señala que las lenguas europeas comparten muchos refranes, y como pruebas de ello enumera varios diccionarios existentes, entre ellos el Dictionary of European Proverbs de Emanuel Strauss o el European Proverbs in 55 Languages de Gyula Paczolay. Existen refranes que expresan un mismo significado pero mediante estructuras (metáforas) diferentes (Mieder, 2000). Por ejemplo:

\begin{tabular}{|l|l|l|}
\hline ESPAÑOL & A gran salto, gran quebranto. & \\
\hline SERBIO & Ko visoko leti, taj nisko pada. & 'el que vuela alto, cae bajo' \\
\cline { 1 - 2 } ESLOVENO & Kdor visoko leta, nizko pade. & \\
\hline
\end{tabular}

Pero, también se han observado 4 fuentes comunes a los refranes europeos (Mieder, 2000: 17-20):

(1) las tradiciones griega y romana, cuyas obras también contenían refranes: 


\begin{tabular}{|l|l|l|}
\hline ESPAÑOL & SERBIO & ESLOVENO \\
\hline Las paredes oyen. & I zidovi imaju uši. & Stene imajo ušesa. \\
\hline El amor es ciego. & Ljubav je slepa. & Ljubezen je slepa. \\
\hline Perro que ladra no muerde. & Pas koji laje ne ujeda. & Pes, ki laja ne grize. \\
\hline
\end{tabular}

(2) la Biblia:

\begin{tabular}{|l|l|l|}
\hline ESPAÑOL & SERBIO & ESLOVENO \\
\hline $\begin{array}{l}\text { Ojo por ojo, diente por } \\
\text { diente. }\end{array}$ & Oko za oko, zub za zub. & Oko za oko, zob za zob. \\
\hline $\begin{array}{l}\text { En casa de este hombre, el } \\
\text { que no trabaja, no come. }\end{array}$ & $\begin{array}{l}\text { Ko leti planduje, zimi gladuje. } \\
\text { ('Quien no trabaja en } \\
\text { verano, en invierno pasa } \\
\text { hambre'); Ko radi, ne boji } \\
\text { se gladi ('Quien trabaja, no } \\
\text { teme al hambre') }\end{array}$ & Kdor ne de, naj ne je. \\
\hline $\begin{array}{l}\text { El que cava un hoyo caerá } \\
\text { en él. }\end{array}$ & $\begin{array}{l}\text { Ko drugome jamu kopa sam } \\
\text { će u nju upasti. }\end{array}$ & $\begin{array}{l}\text { Kdor drugemo jamo koplje, } \\
\text { sam vanjo pade. }\end{array}$ \\
\hline
\end{tabular}

(3) el latín medieval (lingua franca), del que proceden refranes como:

\begin{tabular}{|l|l|l|}
\hline ESPAÑOL & SERBIO & ESLOVENO \\
\hline $\begin{array}{l}\text { Cuatro ojos ven más que } \\
\text { dos. }\end{array}$ & Više vide četiri oka nego dva. & Več glav ${ }^{4}$ več ve. \\
\hline $\begin{array}{l}\text { Todo lo que reluce no es } \\
\text { oro. }\end{array}$ & Nije sve zlato što se sija. & Ni vse zlato, kar se sveti. \\
\hline $\begin{array}{l}\text { Tanto va el cántaro a la } \\
\text { fuente que al final se } \\
\text { rompe. }\end{array}$ & $\begin{array}{l}\text { Krčag ide na vodu dok se ne } \\
\text { razbije. }\end{array}$ & $\begin{array}{l}\text { Vrč hodi po vodo, dokler se } \\
\text { ne razbije. }\end{array}$ \\
\hline $\begin{array}{l}\text { De noche, todos los gatos } \\
\text { son pardos. }\end{array}$ & Noću su sve krave crne. & Ponoči so vse krave črne. $^{\text {cra }}$ \\
\hline
\end{tabular}

(4) textos modernos (desde mediados del siglo XX), como por ejemplo

\begin{tabular}{|l|l|l|}
\hline ESPAÑOL & SERBIO & ESLOVENO \\
\hline $\begin{array}{l}\text { Una imagen vale más que } \\
\text { mil palabras. }\end{array}$ & $\begin{array}{l}\text { Jedna slika vredi više nego } \\
\text { hiljadu reči. }\end{array}$ & $\begin{array}{l}\text { Slika je vredna več kot tisoč } \\
\text { besed. }\end{array}$ \\
\hline
\end{tabular}

4 En la versión eslovena en vez de ojos, se emplea glava, 'cabeza', como en ruso (véase Refranero multilingüe en español en línea: https://cvc.cervantes.es/lengua/refranero/).

5 En las versiones eslovena y serbia aparece vaca (krava) en vez de gato; el mismo lexema aparece en eslovaco y en checo (véase http://www.sprichwort-plattform.org). 
No obstante, en las últimas décadas e incluso en este último siglo se observa una menor presencia de refranes que han sido parcialmente sustituidos por refranes modificados en los que es evidente un carácter humorístico. He aquí algunos ejemplos en las tres lenguas:

\begin{tabular}{|l|l|}
\hline REFRÁN ESPAÑOL & REFRÁN MODIFICADO \\
\hline A quien madruga, Dios le ayuda. & Al que madruga, le ha de gustar la siesta. \\
\hline Haz bien y no mires a quién. & Hazlo bien y no mires con quién. \\
\hline El que ríe último, ríe mejor. & El que ríe último, no entendió el chiste. \\
\hline
\end{tabular}

Tabla 1: Ejemplos de refranes modificados en español

\begin{tabular}{|l|l|l|}
\hline REFRÁN SERBIO & EQUIVALENCIA EN ESPAÑOL & REFRÁN MODIFICADO \\
\hline Ko rano rani, dve sreće grabi. & $\begin{array}{l}\text { A quien madruga, Dios le } \\
\text { ayuda. }\end{array}$ & $\begin{array}{l}\text { Ko rano rani, ceo dan zeva/ } \\
\text { ceo dan mu se spava. ('Quien } \\
\text { madruga, bosteza todo el } \\
\text { día / tiene sueño todo el } \\
\text { día') } \\
\text { Ko rano rani, ili je pekar ili je } \\
\text { budala. ('Quien madruga, o } \\
\text { es panadero o es tonto') } \\
\text { Ko rano rani, nije direktor. } \\
\text { ('Quien madruga, no es } \\
\text { director') }\end{array}$ \\
\hline $\begin{array}{l}\text { Bolje vrabac u ruci nego } \\
\text { golub na grani. }\end{array}$ & $\begin{array}{l}\text { Más vale pájaro en mano } \\
\text { que ciento volando. }\end{array}$ & $\begin{array}{l}\text { Bolje vrabac u ruci nego } \\
\text { govno na glavi. ('Más vale } \\
\text { gorrión en la mano que } \\
\text { mierda en la cabeza') }\end{array}$ \\
\hline $\begin{array}{l}\text { Ko drugome jamu kopa sam } \\
\text { u nju upada. }\end{array}$ & $\begin{array}{l}\text { El que cava un hoyo caerá } \\
\text { en él. }\end{array}$ & $\begin{array}{l}\text { Ko drugome jamu kopa, } \\
\text { taj je zemljoradnik/grobar } \\
\text { /fizikalac. ('El que cava } \\
\text { un hoyo, es agricultor / } \\
\text { sepulturero / constructor') }\end{array}$ \\
\hline $\begin{array}{l}\text { Ono što možeš danas, ne } \\
\text { ostavljaj za sutra. }\end{array}$ & $\begin{array}{l}\text { No dejes para mañana lo } \\
\text { que puedas hacer hoy. }\end{array}$ & $\begin{array}{l}\text { Što možeš sutra, ne ostavljaj } \\
\text { za danas. ('Lo que puedas } \\
\text { hacer mañana, no lo dejes } \\
\text { para hoy') }\end{array}$ \\
\hline
\end{tabular}

Tabla 2: Ejemplos de refranes modificados en serbio ${ }^{6}$

6 Retomamos los ejemplos de: https://vukajlija.com/forum/teme/4642-antiposlovice. 


\begin{tabular}{|l|l|l|}
\hline REFRÁN ESLOVENO & EQUIVALENCIA EN ESPAÑOL & REFRÁN MODIFICADO \\
\hline $\begin{array}{l}\text { Kdor drugemu jamo koplje, } \\
\text { sam vanjo pade. }\end{array}$ & $\begin{array}{l}\text { El que cava un hoyo caerá } \\
\text { en él. }\end{array}$ & $\begin{array}{l}\text { Kdor drugemu jamo koplje, } \\
\text { je grobar/gradbinec. ('El } \\
\text { que cava un hoyo, es } \\
\text { sepulturero/constructor') }\end{array}$ \\
\hline $\begin{array}{l}\text { Rana ura, zlata ura. ('hora } \\
\text { temprana, hora dorada') }\end{array}$ & $\begin{array}{l}\text { A quien madruga, Dios le } \\
\text { ayuda. }\end{array}$ & $\begin{array}{l}\text { Rana ura, slovenskih fantov } \\
\text { grob. ('Hora temprana, } \\
\text { tumba de los muchachos } \\
\text { eslovenos') }\end{array}$ \\
\hline $\begin{array}{l}\text { Kdor visoko leta, nizko pade. } \\
\text { ('el que vuela alto, cae bajo') }\end{array}$ & $\begin{array}{l}\text { A gran salto, gran } \\
\text { quebranto. }\end{array}$ & $\begin{array}{l}\text { Kdor visoko leta, je pilot. ('El } \\
\text { que vuela alto, es piloto') }\end{array}$ \\
\hline $\begin{array}{l}\text { Kar lahko storiš danes, ne } \\
\text { odlašaj na jutri. }\end{array}$ & $\begin{array}{l}\text { No dejes para mañana lo } \\
\text { que puedas hacer hoy. }\end{array}$ & $\begin{array}{l}\text { Kar lahko storiš danes, odloži } \\
\text { na jutri'. ('Deja para mañana } \\
\text { lo que puedas hacer hoy') }\end{array}$ \\
\hline
\end{tabular}

Tabla 3: Ejemplos de refranes modificados en esloveno ${ }^{8}$

Aún más interesante es la presencia de los refranes modificados que van más allá del humor y que más bien incitan al lector a reflexionar sobre el nuevo contenido paremiológico. Estas estructuras a veces se llaman antirrefranes (ing. antiproverbs), y el término se debe a Wolfgang Mieder (2000). Como reflejan los ejemplos, los antirrefranes son el resultado de distintos tipos de transformación de refranes ${ }^{9}$ o de otras estructuras paremiológicas [Te pienso, luego existes (Rafael Marín) < Pienso, luego existo (Descartes)], y suelen usarse como comentarios irónicos, satíricos o por lo menos humorísticos de determinadas situaciones, acontecimientos, personas, etc., por lo que para su interpretación correcta son necesarios conocimientos del contexto social, lingüístico y cultural concreto (Otašević, 2011). En ocasiones, en internet principalmente, es posible encontrar este tipo de estructuras sin referencia al autor, por lo que se parecen más todavía a los refranes:

7 Este antiproverbio parece ser un internacionalismo ya que tiene sus equivalencias también en checo y eslovaco (Meterc, 2014: 115).

8 Retomamos los cinco primeros ejemplos en esloveno de la tabla 3 de Meterc (2014: 114) por el grado de frecuencia y recurrencia entre los hablantes eslovenos según la investigación que realizó el mismo autor en octubre de 2012 (Meterc, 2014: 214).

9 En esta ocasión no pretendemos entrar en el tipo de modificaciones realizadas. No obstante, se han publicado varios trabajos sobre ese tema (véase Reyne, 1997; Palma, 2009; Nenkova, 2016 entre otros). 


\begin{tabular}{|l|l|}
\hline ESPAÑOL & $\begin{array}{l}\text { No robes, los políticos odian la competencia. } \\
\text { El dinero no hace la felicidad, la compra hecha. } \\
\text { Hay un mundo mejor, pero es carísimo. } \\
\text { No hay mujer fea, solo belleza rara. }\end{array}$ \\
\hline SERBIO & $\begin{array}{l}\text { U današnje vreme ne moraš da budeš pametan, dovoljno je da imaš } \\
\text { Smartphone. ('Hoy en día no hace falta que seas inteligente, es } \\
\text { suficiente con que tengas un smartphone') } \\
\text { Ipoštenog čoveka možete pošteno potkupiti, samo morate pošteno i platiti. } \\
\text { ('Hasta un hombre honesto se puede comprar, tan solo hace falta pagar } \\
\text { honestamente') }\end{array}$ \\
\hline ESLOVENO4 & $\begin{array}{c}\text { Za vsakim uspešnim moškim stoji presenečena/stroga žena. ('Detrás de cada } \\
\text { hombre exitoso hay una mujer sorprendida/severa) } \\
\text { Ne kradi, politiki sovražijo konkurenco. ('No robes, los políticos odian la } \\
\text { competencia') } \\
\text { Ljubezen je slepa, spregledamo šele po poroki. ('El amor es ciego, no es } \\
\text { hasta después de la boda cuando empezamos a ver') }\end{array}$ \\
\hline
\end{tabular}

No obstante, por su estructura y contenido, y sobre todo por el tono irónico y agudo, se pueden caracterizar como aforismos. Otras muchas veces sí se hacen referencias a autores, que a menudo publican estas y otras construcciones en forma de diccionarios, blogs, etc. ${ }^{11}$ He aquí más ejemplos de aforismos en forma de antirrefrán con autoría en español, serbio y esloveno:

\begin{tabular}{|l|l|}
\hline REFRÁN ESPAÑOL & ANTIRREFRÁN ESPAÑOL \\
\hline Hablando se entiende la gente. & Hablando se malentiende la gente. (Andrés Ortiz-Osés) \\
\hline El amor es ciego. & El amor es ciego, pero acaba viendo. (Andrés Ortiz-Osés) \\
\hline Por la boca muere el pez. & $\begin{array}{l}\text { Por la boca muere el pez y el escritor de aforismos. } \\
\text { (Ramón Eder) }\end{array}$ \\
\hline Del mal, el menos. & Del yo, el menos. (Andrés Trapiello) \\
\hline La fe mueve montañas. & La fe mueve patrañas. (José Luis Morante) \\
\hline
\end{tabular}

Tabla 4: Ejemplos de antirrefranes españoles de autor conocido

10 Retomamos los ejemplos eslovenos del corpus en línea Gigafida. Todos los ejemplos que se citan pertenecen al discurso periodístico.

11 En la siguiente página web, por ejemplo, se pueden encontrar datos y enlaces interesantes: http://www.elaforista.es/. 


\begin{tabular}{|l|l|}
\hline REFRÁN SERBIO & ANTIRREFRÁN SERBIO \\
\hline $\begin{array}{l}\text { Ko laže, taj i krade. ('Quien } \\
\text { miente, también roba') }\end{array}$ & $\begin{array}{l}\text { Ko laže, taj i krade. Ako poštuje stranačku disciplinu. } \\
\text { (Slobodan Simić) ('Quien miente, también roba. Si } \\
\text { respeta la disciplina del partido') }\end{array}$ \\
\hline $\begin{array}{l}\text { Vreme leči sve. ('El tiempo cura } \\
\text { todo') }\end{array}$ & $\begin{array}{l}\text { Vreme leči sve. Zato se u ambulanti čeka satima. } \\
\text { (Srdjan Dinčić) ('El tiempo cura todo. Por eso en los } \\
\text { ambulatorios se espera durante horas') }\end{array}$ \\
\hline $\begin{array}{l}\text { Pravda je spora, ali dostižna. } \\
\text { ('La justicia es lenta, pero } \\
\text { alcanzable') }\end{array}$ & $\begin{array}{l}\text { Kad je pravda brza, onda je nedostižna.(Aleksandar } \\
\text { Čotrić) ('Cuando la justicia es rápida, es inalcanzable') }\end{array}$ \\
\hline
\end{tabular}

Tabla 5: Ejemplos de antirrefranes serbios de autor conocido

\begin{tabular}{|l|l|}
\hline REFRÁN ESLOVENO & ANTIRREFRÁN ESLOVENO \\
\hline $\begin{array}{l}\text { Kdor laže tudi krade. ('Quien } \\
\text { miente, también roba') }\end{array}$ & $\begin{array}{l}\text { Kdor laže tudi krade. Ampak če si veliko nakradel, nimaš } \\
\text { več potrebe lagati. (Žarko Petan, 1971) ('Quien miente } \\
\text { también roba. Pero, si has robado mucho, ya no tienes } \\
\text { que mentir') }\end{array}$ \\
\hline $\begin{array}{l}\text { Skozi eno uho noter, skozi drugo } \\
\text { ven. } \\
\text { ('Entrar por un oído y salir por } \\
\text { el otro') }\end{array}$ & $\begin{array}{l}\text { Možgani so ovira za misli, ki pridejo skozi eno uho noter in } \\
\text { gredo skozi drugo uho ven. (Žarko Petan, 1971) } \\
\text { ('El cerebro es el obstáculo para los pensamientos que } \\
\text { entran por un oído y salen por el otro') }\end{array}$ \\
\hline $\begin{array}{l}\text { Kdor se zadnji smeje, se najslajše } \\
\text { smeje. (Quien ríe el último, ríe } \\
\text { mejor). }\end{array}$ & $\begin{array}{l}\text { Kdor se zadnji smeje, se bo smejal sam (Žarko Petan, } \\
\text { 2011) ('Quien ríe el último, reirá solo') }\end{array}$ \\
\hline
\end{tabular}

Tabla 6: Ejemplos de antirrefranes eslovenos de autor conocido

Los antirrefranes parecen confirmar adicionalmente la expresividad como una característica muy importante de los refranes y las paremias en general, pero asimismo muestran la dinamicidad de estas estructuras, puesto que algunas de ellas son bases adecuadas para la producción de otras nuevas. ${ }^{12}$ Como señala Mieder (1997: 416), y según puede verse en los ejemplos, estas nuevas paremias no necesariamente tienen carácter didáctico o prescriptivo, pero sí tienen un importante valor pragmático y un potencial expresivo muy alto, precisamente debido a la ironía, la sátira, el humor presente.

\subsection{El aforismo}

En su excelente Introducción a la recopilación de los aforismos, González (2013) señala que no hay una definición uniforme del aforismo debido a que a lo largo 12 Para más ejemplos, véase Mieder 2000 y Combet 1996. 
de su evolución se ha relacionado con otras formas breves. Para Munguía Zatarain y Rocha Romero (2003: 315), los aforismos son enunciados completos que encierran una conclusión o una reflexión. Explican las autoras:

El aforismo permite descubrir lo que está encubierto por la herencia cultural; se trata de verdades que tienen valor no porque sean verificables mediante procedimientos lógicos, sino que su valor radica en que dicen algo nuevo e inesperado, obligan al lector a reflexionar sobre otra dimensión de la realidad, provocan significaciones novedosas, aún no conocidas, y por ello parecen en ocasiones grandes absurdos o grandes verdades (Munguía Zatarain y Rocha Romero, 2003: 317)

Los orígenes del pensamiento aforístico datan ya del siglo XIV, en las Glosas de Sabiduría o Proverbios Morales de Don Sem Tob (Gutiérrez Pérez y Pérez Romero, 2012: 169). En la Edad Media y a principios del Renacimiento con el término aforismo «se aludía a una breve sentencia que resumía con ingenio un saber médico o jurídico, sobre todo» (Gutiérrez Pérez y Pérez Romero, 2012: 169), debido a la influencia de Hipócrates y sus Aforismos. Muy rápido, sin embargo, este género empezó a cultivarse también en la literatura, donde se conocía con diferentes nombres, siendo máxima uno de ellos. Sin embargo, según Biason (2004, apud Gutiérrez Pérez y Pérez Romero, 2012: 171), la diferencia entre una máxima y un aforismo consiste en la falta de gravedad ${ }^{13}$ en el aforismo (por lo cual se confunde con una broma) y las ideas fulgurantes que conlleva, «pidiendo al lector una rapidez de reacción impensable en la máxima clásica». Para Nemer (1982, apud Gutiérrez Pérez y Pérez Romero, 2012: 172 $)^{14}$, la máxima se caracteriza por su didacticismo así como por su aristocratismo, puesto que pertenece a la clase aristocrática. A partir de la segunda mitad del siglo XVI se amplía el significado de aforismo, que pasa a significar «pensamiento o reflexión en general breve y de carácter doctrinal», para posteriormente, en el siglo XVII, significar «verdad de experiencia o breve formulación de carácter general, por lo más con uso didáctico» (Gutiérrez Pérez y Pérez Romero, 2012: 170).15

13 Sevilla Muñoz y Crida Álverez (2013), como hemos visto, sí destacan el tono grave de los aforismos, igual que el tono grave de los proverbios.

14 Se trata del siguiente trabajo: Nemer, Monique. 1982. «Les intermittences de la verité: Maxime, sentence ou aphorisme: notes sur l'évolution d'un genre». Studi francesi, 78, 484-493.

15 González (2013) recuerda que a lo largo de su evolución, el aforismo se ha relacionado también con la greguería, creada por Ramón Gómez de la Serna. Como se trata de una forma típticamente española, en este trabajo no vamos a detenernos en ella. 
Respecto a la relación del aforismo con la máxima y la sentencia, González (2013) opina que el aforismo tiene que ver con estas dos formas más bien en su versión o acepción clásica, mientras que el aforismo moderno supone una forma diferente. A diferencia de la máxima y la sentencia, que «suelen adoptar una forma descriptiva y tienen un carácter prescriptivo» $\mathrm{y}$ «tratan de establecer verdades universales e intemporales» (González, 2013: 25), el aforismo moderno es justo lo contrario: es una forma que pertenece a un sujeto concreto, que presenta «verdades parciales y provisionales, propias de un autor y de un momento y una circunstancia concreta, que aspiran a dar cuenta de un pensamiento en acción, liberado de cualquier atadura lógico-retórica» (González, 2013: 27). Munguía Zatarain y Rocha Romero (2003: 316) anteriormente destacaron que

el aforismo [...] es un tipo de discurso que pudiéramos calificar como intrigante, como provocador, puesto que pretende introducir la duda, resquebrajar lo firme y dar un valor a lo incierto, a lo otro, a lo que se nos ha ocultado; para hacerlo, da la impresión de formular una gran verdad -aunque todos sabemos que no necesariamente lo es- para cuestionar y poner en tela de juicio esas certezas e ideas preconcebidas y, con ello, provocar la incertidumbre.

A diferencia de los refranes y proverbios, que en principio son autónomos y reflejan la sabiduría popular (Corpas Pastor, 1996), «los aforismos son el producto de una construcción cuidadosa y medida, en la que el autor pone en juego muy conscientemente su capacidad como creador» y sus principales características son la «brevedead, concisión, capacidad de sugerencia» (González, 2013: 33). La densidad es otro rasgo importante de los aforismos, puesto que permiten «una máxima expansión semántica empleando el mínimo de palabras posibles» (González, 2013: 37). A pesar de que son formas sintácticamente cerradas, al mismo tiempo son abiertas, porque invitan al lector a pensar, reflexionar, cuestionar. Ello se consigue, a menudo, mediante la ironía, la paradoja, la inversión, el doble sentido y otros mecanismos (González, 2013: 36) que involucran al lector, que hacen que relea una y otra vez el contenido, reflexione sobre lo que se ha expresado, lo cuestione o se le acerque desde distintos puntos de vista. La ironía significa el enfrentamiento del espíritu humano a la tendencia humana de mostrar la dominación de su personalidad sobre lo que le rodea, lo que le agobia y lo que amenaza destrozar sus energías vitales interiores (Jovanović, 2006: 274). El tono y el contenido del aforismo 
«parecen axiomáticos, pero nacen de la incertidumbre, indagan en zonas precarias de la verdad» (Martínez, 2012: 14).

Los aforismos se crean en muy diversos ámbitos de la vida, por lo que a continuación presentamos tan solo algunos ejemplos de aforismos actuales en español, serbio y esloveno:

\begin{tabular}{|c|c|}
\hline ESPAÑOL $^{16}$ & $\begin{array}{l}\text { El silencio es políglota. (Carlos Edmundo de Ory) } \\
\text { La ironía delata a los cuerdos. (Ramón Eder) } \\
\text { Cuánto debemos crecer para pasar inadvertidos. (Erika Martínez) } \\
\text { No cambies: varía. (Ángel Crespo) } \\
\text { En la música hay un más allá convertido en un más acá. (Vicente Núñez) } \\
\text { El egoísta hace del yo apócope de nosotros. (José Luis Morante) } \\
\text { Prefiero tener un pasado a vivir en subjuntivo. (Carmen Camacho) } \\
\text { Brevedad, cuán larga eres. (Andrés Neuman) }\end{array}$ \\
\hline SERBIO $^{17}$ & $\begin{array}{l}\text { Ovan je harizmatična ličnost. Celo stado ide za njim. (Aleksandar Čotrić) ('El } \\
\text { carnero tiene una personalidad carismática. Todo el rebaño va tras él') } \\
\text { Opustite se. Ne preti nam nikakva budućnost. (Vesna Denčić) ('Relájense. No } \\
\text { nos amenaza ningún futuro') } \\
\text { Zemlja je vraćena seljacima, ali ih nije zatekla tamo. (Rade Djergović) ('La } \\
\text { tierra ha sido devuelta a los campesinos, pero no los ha encontrado allí') } \\
\text { Zabrinjava nas njihovo mentalno stanje. Počeli su da misle svojom glavom. } \\
\text { (Rade Djergović) ('Nos preocupa su estado mental. Han empezado a } \\
\text { pensar con su propia cabeza') }\end{array}$ \\
\hline ESLOVENO $^{18}$ & $\begin{array}{l}\text { Najbolj nevarne misli se rodijo v praznih glavah. ('Los pensamientos más } \\
\text { peligrosos nacen en las cabezas vacías') } \\
\text { Obljube so hitro pokvarljivo blago. ('Las promesas son una mercancía } \\
\text { perecedera') } \\
\text { Pesniki živijo večno, a na žalost šele po smrti. ('Los poetas viven } \\
\text { eternamente, pero desgraciadamente no antes de que se mueran') } \\
\text { Amnezija je bolezen ljudi, ki vedo preveč. ('La amnesia es una enfermedad } \\
\text { de la gente que sabe demasiado') }\end{array}$ \\
\hline
\end{tabular}

Tabla 7: Ejemplos de aforismos en español, serbio y esloveno

16 Retomamos los ejemplos en español de González 2013.

17 Los ejemplos en serbio se encuentran en: http://www.aforizam.com.

18 Todos los ejemplos citados son del escritor, director de cine y prolífico aforista esloveno Žarko Petan. Retomamos los ejemplos de la selección de Milič (2011): http://www.locutio. si/index.php? no= 59 \& clanek=1518. 
Los más llamativos probablemente son los aforismos sobre temas políticos y sociales:

\begin{tabular}{|l|l|}
\hline ESPAÑOL & $\begin{array}{l}\text { Mejor no probar el poder: podría gustarnos. (Carlos Castilla del Pino) } \\
\text { La política es la matemática del poder. (Ángel Guinda) } \\
\text { Un político es un ciudadano menos. (Ramón Eder) } \\
\text { La lucha por el poder suele ser terrible, pero la lucha por las migajas del poder } \\
\text { es siempre patética. (Ramón Eder) }\end{array}$ \\
\hline SERBIO'19 & $\begin{array}{l}\text { Oni znaju šta narod hoće. Zato narod niko ine pita. (Srba Pavlović) ('Ellos } \\
\text { saben lo que quiere el pueblo. Por eso al pueblo nadie le pregunta nada') } \\
\text { Cenzura je ukinuta - jer je sve pod kontrolom. (Srba Pavlović) ('La censura se } \\
\text { ha quitado porque está todo bajo control') } \\
\text { Crveni oktobar plus crveni jul jednako je crni petak. (Ilija Marković) ('El } \\
\text { octubre rojo más el julio rojo es igual al viernes negro') } \\
\text { Odrastao sam u komunizmu, što je samo po sebi uspeh. (Vladan Sokić) ('He } \\
\text { crecido en el comunismo, lo que es un éxito por sí mismo') }\end{array}$ \\
\hline $\begin{array}{l}\text { Strah je gospod s kravato21. ('El miedo es un señor con corbata') } \\
\text { Politiki mešajo karte na mizi, delijo pa jih pod mizo. ('Los políticos barajan } \\
\text { las cartas sobre la mesa, pero las reparten debajo de ella') } \\
\text { Politik mora imeti trdo kožo, trdo glavo in mehka stališča. ('El político tiene } \\
\text { que tener "la piel dura"22, la "cabeza dura"23 y las actitudes tiernas') }\end{array}$ \\
\hline
\end{tabular}

Tabla 8: Ejemplos de aforismos políticos y sociales en español, serbio y esloveno

El desarrollo de las nuevas tecnologías y la aparición de redes sociales han contribuido a la difusión pero también al desarrollo de aforismos. Una de las razones a las que se debe el auge del aforismo reside en que «los mensajes de las redes sociales, sometidos a la estrechez verbal, han entrenado a millones de personas en una comunicación cuyo alcance optimizan las herramientas literarias de la brevedad» (Martínez, 2012: 16). Más aún, «el aforismo reconcilia la creación literaria y el pensamiento filosófico y moral con los requerimientos de la velocidad del mundo actual en que cada vez menos personas se toman el tiempo para leer una obra extensa» (Brander, 2015: 20). Por tanto, «los

19 Retomamos los ejemplos de: https://www.aforizam.com y https://www.aforizmi.org.

20 Los últimos dos ejemplos son del prolífico aforista esloveno Žarko Petan. Retomamos los ejemplos de la selección de Milič (2011), http://www.locutio.si/index. php? no= 59 \& clanek $=1518$.

21 http://enpassant.blog.siol.net/2012/10/24/aforizem-politicni-6/

22 En español se pierde el juego semántico: imeti trdo kožo 'tener la piel dura' significa en esloveno ser poco sensible, no ofenderse fácilmente.

23 En español se pierde el juego semántico: biti trde glave 'tener la cabeza dura' significa en esloveno ser torpe. 
aforismos parecen la vía ideal para alcanzar honduras filosóficas sin quemarse las pestañas» (Fraguas, 2011).

\section{A modo de conclusión}

Si un refrán corresponde a la sabiduría popular, sabiduría colectiva, si forma parte de una determinada cultura, de determinados valores y actitudes tradicionales, y si tenemos en cuenta que las culturas cambian a lo largo del tiempo, debido a factores internos y externos, entonces no es de extrañar que algunos o muchos de ellos con el tiempo hayan caído en desuso o hayan sido adaptados a nuevas circunstancias. Eso significa que una determinada comunidad cultural, comunidad lingüística, está en constante búsqueda de vías y maneras de expresar, transmitir, retener, recordar o simplemente comentar las nuevas experiencias, convertidas a veces en nuevas costumbres, nuevos valores, nuevas tradiciones, o que por lo menos incitan a la reflexión. Con el tiempo y debido a los cambios a los que se ha enfrentado una determinada comunidad, algunos (si no muchos) refranes, como formas de valor pedagógico puesto que expresan el saber basado en la experiencia dentro de una determinada cultura, han perdido la fuerza y la contundencia de su valor semántico, su poder de convencer, su poder de formar y arraigar valores. Asimismo, las supuestas verdades que encierran los refranes con el tiempo se muestran pasajeras, incluso falsas, ridículas o absurdas, lo cual hace que esas construcciones ya no sean necesarias, porque ya no cumplen su función didáctica.

El refrán y el aforismo, junto con otros subtipos de paremias, han existido paralelamente y han mostrado ser formas dinámicas. En cierto sentido, el aforismo podría interpretarse como el contrapeso del refrán: si el refrán es el reflejo de una supuesta sabiduría popular, que hay que aceptar como tal, casi como un dogma sin cuestionarlo, el aforismo es la voz interior, que necesita salir a la superficie, no solo para oponerse, a veces, a ese saber colectivo, sino para ver con sus propios ojos el mundo de su alrededor y expresar lo que ve con sus propias palabras, a su propia manera, con sus propias imágenes. Debido al desarrollo de la sociedad en general y a los avances culturales, y también gracias al desarrollo del intelecto humano y a la libertad de la opinión, los aforismos, como pensamientos libres, agudos, hasta atrevidos, rebeldes y provocadores, y por la manera concisa, sucinta y reflexiva con la que se caracterizan, corresponden más al carácter de la sociedad contemporánea. Observando los ejemplos citados en las tres lenguas hemos podido comprobar que su componente pedagógico sigue estando presente, aunque estas formas breves no sirven para enseñar de una 
manera directa, sino que más bien invitan a la reflexión, despiertan intelectos adormecidos, lo cual, en realidad, es la enseñanza a largo plazo, de por vida.

\section{Bibliografía}

\section{Fuentes electrónicas}

https://cvc.cervantes.es/lengua/refranero/

https://www.aforizam.com

https://www.aforizmi.org

http://www.gigafida.net/

\section{Referencias bibliográficas}

Brander, M. L. (2015): “¿Gracias a Twitter, reviven los aforismos?’ - Las formas breves en Internet». MERIDIONAL Revista Chilena de Estudios Latinoamericanos, 5, 13-40.

Combet, L. (1995): «Los refranes: origen, función y futuro». Paremia, 5, 11-22. Conde Tarrío, G. (ed.) (2007): El componente etnolingüistico de la Paremiología. Fernelmont: Editions Modulaires Européennes.

Corpas Pastor, G. (1996): Manual de fraseología española. Madrid: Gredos.

Estébanez Calderón, D. (2008): Diccionario de términos literarios. Madrid: Alianza Editorial.

Fraguas, A. (2011): «La filosofía del 'pienso, luego tuiteo'. Twitter y otras herramientas de Internet insuflan nuevos aires al aforismo». El País. El periódico global, 3 de abril de 2011: http://elpais.com/diario/2011/04/o3/ cultura/1301781601_850215.html (25-10-2016).

González, J. R. (2013): Pensar por lo breve. Aforistica española de entresiglos. Antología (1980-2012). Gijón: Trea.

Gutiérrez Pérez, R., Pérez Romero, J. (2012): «El cultivo del aforismo en España». AnMal, XXXV, 169-177.

Jovanović, J. (2006): Knjiga srpskib narodnib poslovica I. Beograd: Naučno društvo za negovanje i proučavanje srpskog jezika.

Junceda, L. (2003): Diccionario de refranes. Madrid: Espasa.

Karadžić, V. ([1849] 1977): Srpske narodne poslovice $i$ druge različne keo one u običaj uzete riječi. Beograd: Nolit.

Keber, J. (2011): Slovar slovenskib frazemov. Ljubljana: Zalozba ZRC. 
Kržišnik, E. (2008): Viri za kulturološko interpretacijo frazeoloških enot. Jezik in slovstvo, 53, 1, 33-47.

Martínez, E. (2012): «Añicos. El aforismo español de los siglos XX y XXI». Mercurio, 137, 14-16.

Martínez, E. (2013): «Ideas en desbandada. Notas sobre el aforismo contempráneo». Insula, 801, 3-7.

Meterc, M. (2014): «Je prihodnost slovenskih antipregovorov (le) pregovorna?» En: Tivadar Hotimir (ed.), Pribodnost v slovenskem jeziku, literaturi in kulturi. 50. Seminar slovenskega jezika, literature in kulture. Ljubljana: Filozofska fakulteta, Center za slovenščino kot drugi/tuji jezik, 113-116.

Mieder, W. (1997): «Modern Paremiology in Retrospect and Prospect». Paremia, 6, 399-416.

Mieder, W. (2000): «Historia y futuro de los refranes comunes en Europa». Paremia, 9, 15-24.

Milič, J. (2011): «Žarko Petan. Aforizmi-aforismi». Locutio, 59: http://www. locutio.si/index.php? no=59\&clanek=1518 (03-09-2017).

Munguía Zatarain, I., Rocha Romero, G. (2003): «Hacia una concepción del aforismo como un nuevo discurso crítico». Poligrafías, IV, 231-241.

Otašević, D. (2011): Rečnik srpskih antiposlovica: http://www.aforizmi.org/etna (25-03-2016).

Pamies Bertrán, A. (2008): «Productividad fraseológica y competencia metafórica (inter)cultural». Paremia, 17, 41-58.

Pejović, A. (2013): «La expresión fraseológica de los valores éticos y estéticos». Colindancias, 4, 265-273.

Pejović, A. (2014): «Paremije kao deo etnolingvističkog nasledja». Glasnik Etnografskog instituta SANU, 62, 2, 201-214.

Pejović, A. (2015): Kontrastivna frazeologija španskog i srpskog jezika. Kragujevac: Filološko-umetnički fakultet.

Penadés Martínez, I. (2006): «El valor discursivo de los refranes». ELUA, 20, 287-304.

Petan, Ž. (1971): «Slečene misli». Sodobnost, 19, 1, 11-12.

Pihler Ciglič, B. (2006): «Sancho Panza: prevaricador del buen lenguaje: análisis contrastivo esloveno - español». En: Branka Kalenić Ramšak, Maja Šabec (eds.), Interpretaciones del Quijote, Ljubljana: Znanstvenoraziskovalni inštitut Filozofske fakultete, 163-180. 
Pihler Ciglič, B. (2007): «Don Quijote y su lenguaje: juegos de palabras en cuanto a la forma y la significación». En: Klaus-Dieter Ertler, Alejandro Rodríguez Díaz del Real (eds.), El Quijote boy: la riqueza de su recepción. Madrid/Frankfurt am Main: Iberoamericana/Vervuert, 225-254.

Platas Tasende, A. M. (2004): Diccionario de términos literarios. Madrid: Espasa.

Reyne, C. (1997): «Algunas consideraciones sobre los falsos refranes en español». Paremia, 6, 531-535.

Sevilla Muñoz, J. (1996): «Sobre la paremiología española». EUSKERA, XLI, 2, 641-672: http://www.euskaltzaindia.eus/dok/euskera/49699.pdf (20-10-2016).

Sevilla Muñoz, J., Crida Álvarez, C. A. (2013): «Las paremias y su clasificación». Paremia, 22, 105-114.

Tarnovska, O. (2006): «Sobre los refranes de El Quijote». Didáctica. Lengua y Literatura, 17, 285-300. Disponible en http://revistas.ucm.es/index.php/ DIDA/article/view/20205 (07-05-2016). 


\author{
Andjelka Pejović \\ University of Belgrade \\ Barbara Pihler Ciglič \\ University of Ljubljana
}

\title{
On the paremiological continuum
}

Key words: paremia, proverb, saying, anti-proverb, aphorism, paremiological continuum

The present study takes as a starting point the famous quotation from Don Quixote "I think, Sancho, there is no proverb that is not true, all being maxims drawn from experience itself, the mother of all the sciences", and aims to investigate sayings and proverbs in general with special attention precisely to that "experience itself", taking into account the cultural foundations of each language community as well as those established through dialogue between different cultures. The main objective is to show, through the examples in Spanish, Serbian and Slovenian, the gnoseological relativism of proverbs and sayings which is necessarily reflected in the structure and use of these constructions. The study also discusses why proverbs fall into disuse and presents some modern equivalent mechanisms and forms. 


\author{
Andjelka Pejović \\ Univerua v Beogradu \\ Barbara Pihler Ciglič \\ Univerza v Ljubljani
}

\title{
O paremiološkem kontinuumu
}

Ključne besede: paremija, pregovor, antipregovor, aforizem, paremiološki kontinuum

V pričujočem članku, ki izhaja iz znane Kihotove misli »Zdi se mi, Sančo, da ga ni pregovora, ki bi ne bil resničen, zakaj vsi so reki, povzeti iz izkušnje same, ki je mati vseh znanosti«, si prizadevamo pregovore in reke osvetliti predvsem s stališča »izkušnje same in pri tem upoštevati tako kulturne temelje posamezne jezikovne skupnosti kot tudi tiste, ki se vzpostavljajo z dialogom med različnimi kulturami. Osrednji cilj raziskave je s primeri v španščini, srbščini in slovenščini pokazati na gnoseološki relativizem pregovorov in rekov, ki se neobhodno zrcali v zgradbi in jezikovni rabi teh struktur. Študija poskuša hkrati odgovoriti na vprašanje, zakaj raba pregovorov upada, ter predstavi nekatere sodobne mehanizme in oblikovne ustreznice. 